\title{
Theoretical Propositions of Life-Span Developmental Psychology: On the Dynamics Between Growth and Decline
}

\author{
Paul B. Baltes \\ Max Planck Institute for Human Development and Education \\ Berlin, Federal Republic of Germany
}

\begin{abstract}
Life-span developmental psychology involves the study of constancy and change in behavior throughout the life course. One aspect of life-span research has been the advancement of a more general, metatheoretical view on the nature of development. The family of theoretical perspectives associated with this metatheoretical view of life-span developmental psychology includes the recognition of multidirectionality in ontogenetic change, consideration of both age-connected and disconnected developmental factors, a focus on the dynamic and continuous interplay between growth (gain) and decline (loss), emphasis on historical embeddedness and other structural contextual factors, and the study of the range of plasticity in development. Application of the family of perspectives associated with life-span developmental psychology is illustrated for the domain of intellectual development. Two recently emerging perspectives of the family of beliefs are given particular attention. The first proposition is methodological and suggests that plasticity can best be studied with a research strategy called testing-the-limits. The second proposition is theoretical and proffers that any developmental change includes the joint occurrence of gain (growth) and loss (decline) in adaptive capacity. To assess the pattern of positive (gains) and negative (losses) consequences resulting from development, it is necessary to know the criterion demands posed by the individual and the environment during the lifelong process of adaptation.
\end{abstract}

The study of life-span development is not a homogeneous field. It comes in two major interrelated modes. The first mode is the extension of developmental studies across the life course without a major effort at the construction of metatheory that emanates from life-span work. The second mode includes the endeavor to explore whether life-span research has specific implications for the general nature of developmental theory. The second approach represents the topic of this article.

Specifically, the purpose of this article is twofold. First, after a brief introduction to the field of life-span developmental psychology, some "prototypical" features of the life-span approach in developmental psychology are presented. Second, these features are illustrated by work in one domain: intellectual development. Although the focus of this paper is on life-span developmental psychology and its theoretical thrust, it is important to recognize at the outset that similar perspectives on developmental theory have been advanced in other quarters of developmental scholarship as well (Hetherington \& Baltes, in press; Scarr, 1986). There is, however, a major difference in the "gestalt" in which the features of the theoretical perspective of life-span psychology are organized.

This article is based on invited addresses to Division 7 of the American Psychological Association (Toronto, Canada, August 1984) and to the International Society for the Study of Behavioral Development (Tours, France, July 1985).

Helpful suggestions by Michael Chapman and many valuable discussions with members of the Social Science Research Council Committee on Life-Course Perspectives in Human Development are acknowledged.

Correspondence concerning this article should be addressed to Paul B. Baltes, Max Planck Institute for Human Development and Education, Lentzeallee 94, D-1000 Berlin 33, Federal Republic of Germany.
Several, if not most, of the arguments presented here are consistent with earlier publications by the author and others on the field of life-span developmental psychology (Baltes, 1983; Baltes \& Reese, 1984; Featherman, 1983; Honzik, 1984; Lerner, 1984; Sherrod \& Brim, 1986). This article includes two added emphases. First, it represents an effort to illustrate the implications of the theoretical perspectives associated with life-span work for research in cognitive development. Second, two of the more recent perspectives derived from life-span work are given special attention. The first is that any process of development entails an inherent dynamic between gains and losses. According to this belief, no process of development consists only of growth or progression. The second proposition states that the range of plasticity can best be studied with a research strategy called testing-the-limits.

\section{What is Life-Span Development?}

Life-span developmental psychology involves the study of constancy and change in behavior throughout the life course (ontogenesis), from conception to death. ${ }^{1}$ The goal is to obtain knowledge about general principles of life-long development, about interindividual differences and similarities in development, as well as about the degree and conditions of individual plasticity or modifiability of development (Baltes, Reese, \& Nesselroade, 1977; Lerner, 1984; Thomae, 1979).

\footnotetext{
${ }^{1}$ In this article, the terms life span and life course are used interchangeably. Since the origin of the West Virginia Conference Series (Goulet \& Baltes, 1970), psychologists tend to prefer life span (see, however, Bühler, 1933), whereas sociologists lean toward the use of the term life course.
} 
It is usually assumed that child development, rather than lifespan development, was the subject matter of the initial scholarly pursuits into psychological ontogenesis. Several historical reviews suggest that this generalization is inaccurate (Baltes, 1983; Groffmann, 1970; Reinert, 1979). The major historical precursors of scholarship on the nature of psychological development-by Tetens in 1777, Carus in 1808, Quetelet in 1835were essentially life-span and not child-centered in approach. Despite these early origins of life-span thinking, however, lifespan development has begun to be studied empirically only during the last two decades by researchers following the lead of early twentieth century psychologists such as Charlotte Bühler (1933), Erik H. Erikson (1959), G. Stanley Hall (1922), H. L. Hollingworth (1927), and Carl G. Jung (1933).

Three events seem particularly relevant to the more recent burgeoning of interest in life-span conceptions: (a) population demographic changes toward a higher percentage of elderly members; (b) the concurrent emergence of gerontology as a field of specialization, with its search for the life-long precursors of aging (Birren \& Schaie, 1985); and (c) the "aging" of the subjects and researchers of the several classical longitudinal studies on child development begun in the 1920s and 1930s (Migdal, Abeles, \& Sherrod, 1981; Verdonik \& Sherrod, 1984). These events and others have pushed developmental scholarship toward recognizing the entire life span as a scientifically and socially important focus.

Added justification for a life-span view of ontogenesis and important scholarly contributions originate in other disciplines as well. One such impetus for life-span work comes from sociology and anthropology (Bertaux \& Kohli, 1984; Brim \& Wheeler, 1966; Clausen, 1986; Dannefer, 1984; Elder, 1985; Featherman, 1983; Featherman \& Lerner, 1985; Kertzer \& Keith, 1983; Neugarten \& Datan, 1973; Riley, 1985; Riley, Johnson, \& Foner, 1972). Especially within sociology, the study of the life course and of the interage and intergenerational fabric of society is enjoying a level of attention comparable with that of the life-span approach in psychology.

Another societal or social raison d'être for the existence of life-span interest is the status of the life course in longstanding images that societies and their members hold about the life span (Philibert, 1968; Sears, 1986). In the humanities, for example, life-span considerations have been shown to be part of everyday views of the structure and function of the human condition for many centuries. The Jewish Talmud, Greek and Roman philosophy (e.g., the writings of Solon and Cicero), literary works such as those of Shakespeare, Goethe, or Schopenhauer, all contain fairly precise images and beliefs about the nature of life-long change and its embeddedness in the age-graded structure of the society. Particularly vivid examples of such social images of the life span come from the arts. During the last centuries, many works of art were produced, reproduced, and modified in most European countries, each using stages, steps, or ladders as a framework for depicting the human life course (Joerißen \& Will, 1983; Sears, 1986).

These observations on literature, art history, and social images of the life course suggest that the field of life-span development is by no means an invention of developmental psychologists. Rather, its recent emergence in psychology reflects the perhaps belated effort on the part of psychologists to attend to an aspect of the human condition that is part and parcel of our everyday cultural knowledge systems about living organisms. Such social images suggest that the life course is something akin to a natural, social category of knowledge about ontogenesis and the human condition.

\section{Is Life-Span Development a Theory or a Field of Specialization?}

What about the theoretical spectrum represented by life-span developmental psychology? Is it a single theory, a collection of subtheories, or just a theoretical orientation? Initial interest often converges on the immediate search for one overarching and unifying theory such as Erikson's (1959). The current research scene suggests that in the immediate future life-span developmental psychology will not be identified with a single theory. It is above all a subject matter divided into varying scholarly specializations. The most general orientation toward this subject matter is simply to view behavioral development as a lifelong process.

Such a lack of theoretical specificity may come as a surprise and be seen as a sign that the life-span perspective is doomed. In fact, the quest for a single, good theory (and the resulting frustration when none is offered) is an occasional challenge laid at the doorsteps of life-span scholars (Kaplan, 1983; Scholnick, 1985; Sears, 1980). Note, however, that the same lack of theoretical specificity applies to other fields of developmental specialization. Infant development, child development, gerontology, are also not theories in themselves, nor should one expect that there would be a single theory in any of these fields. In fact, as long as scholars look for the theory of life-span development they are likely to be disappointed.

\section{A Family of Perspectives Characterizes the Life-Span Approach}

Much of life-span research proceeds within the theoretical scenarios of child developmental or aging work. In addition, however, efforts have been made by a fair number of life-span scholars to examine the question of whether life-span research suggests a particular metatheoretical world view (Reese \& Overton, 1970) on the nature of development. The theoretical posture proffered by this endeavor is the focus of the remainder of this article.

For many researchers, the life-span orientation entails several prototypical beliefs that, in their weighting and coordination, form a family of perspectives that together specify a coherent metatheoretical view on the nature of development. The significance of these beliefs lies not in the individual items but in the pattern. Indeed, none of the individual propositions taken separately is new, which is perhaps one reason why some commentators have argued that life-span work has little new to offer (Kaplan, 1983). Their significance consists instead in the whole complex of perspectives considered as a metatheoretical world view and applied with some degree of radicalism to the study of development.

What is this family of perspectives, which in their coordinated application characterizes the life-span approach? Perhaps no single set of beliefs would qualify in any definite sense. However, the beliefs summarized in Table 1 are likely to be shared by many life-span scholars. They can be identified pri- 
Table 1

Summary of Family of Theoretical Propositions Characteristic of Life-Span Developmental Psychology

Concepts

Life-span development

Multidirectionality

Development as gain/loss

Plasticity

Historical embeddedness

Contextualism as paradigm

Field of development as multidisciplinary
Propositions

Ontogenetic development is a life-long process. No age period holds supremacy in regulating the nature of development. During development, and at all stages of the life span, both continuous (cumulative) and discontinuous (innovative) processes are at work.

Considerable diversity or pluralism is found in the directionality of changes that constitute ontogenesis, even within the same domain. The direction of change varies by categories of behavior. In addition, during the same developmental periods, some systems of behavior show increases, whereas others evince decreases in level of functioning.

The process of development is not a simple movement toward higher efficacy, such as incremental growth. Rather, throughout life, development always consists of the joint occurrence of gain (growth) and loss (decline).

Much intraindividual plasticity (within-person modifiability) is found in psychological development. Depending on the life conditions and experiences by a given individual, his or her developmental course can take many forms. The key developmental agenda is the search for the range of plasticity and its constraints.

Ontogenetic development can also vary substantially in accordance with historical-cultural conditions. How ontogenetic (age-related) development proceeds is markedly influenced by the kind of sociocultural conditions existing in a given historical period, and by how these evolve over time.

Any particular course of individual development can be understood as the outcome of the interactions (dialectics) among three systems of developmental influences: age-graded, historygraded, and nonnormative. The operation of these systems can be characterized in terms of the metatheoretical principles associated with contextualism.

Psychological development needs to be seen in the interdisciplinary context provided by other disciplines (e.g., anthropology, biology, sociology) concerned with human development. The openness of the life-span perspective to interdisciplinary posture implies that a "purist" psychological view offers but a partial representation of behavioral development from conception to death. marily from the writings in psychology on this topic (Baltes \& Reese, 1984; Baltes, Reese, \& Lipsitt, 1980; Lerner, 1984; Sherrod \& Brim, 1986), but they are also consistent with sociological work on the life course (Elder, 1985; Featherman, 1983; Riley, 1985).

The family of beliefs will be illustrated below, primarily using the study of intellectual development as the forum for exposition. Because, historically, the period of adulthood was the primary arena of relevant research, that age period receives most coverage. It will also be shown, however, that the metatheoretical posture may shed new light on intellectual development in younger age groups as well.

\section{Empirical Illustration: Research on Intellectual Development}

The area of intellectual functioning is perhaps the best studied domain of life-span developmental psychology. The discussion and elaboration of the empirical and conceptual bases of the family of perspectives presented here is selective. The intent is not to be comprehensive but to offer examples of areas of research. (Different research findings and agendas-see, for instance, Keating \& MacLean, in press; Perlmutter, in press; Sternberg, in press, for other similar efforts-could have been used were it not for the particular preferences of the author.) More detailed information on the topic of life-span intelligence is contained in several recent publications (Baltes, Dittmann-
Kohli, \& Dixon, 1984; Berg \& Sternberg, 1985; Denney, 1984; Dixon \& Baltes, 1986; Labouvie-Vief, 1985; Perlmutter, in press; Rybash, Hoyer, \& Roodin, 1986; Salthouse, 1985).

\section{Intellectual Development Is a Life-Long Process Involving Multidirectionality}

The first two of the family of perspectives (see Table 1) state that behavior-change processes falling under the general rubric of development can occur at any point in the life course, from conception to death. Moreover, such developmental changes can display distinct trajectories as far as their directionality is concerned.

Life-long development. The notion of life-long development implies two aspects. First, there is the general idea that development extends over the entire life span. Second, there is the added possibility that life-long development may involve processes of change that do not originate at birth but lie in later periods of the life span. Considered as a whole, life-long development is a system of diverse change patterns that differ, for example, in terms of timing (onset, duration, termination), direction, and order.

One way to give substance to the notion of life-long development is to think of the kinds of demands and opportunities that individuals face as they move through life. Havighurst's (1948/ 1972; Oerter, 1986) formulation of the concept of developmental tasks is a useful aid for grasping the notion of a life-long 
system of demands and opportunities. Developmental tasks involve a series of problems, challenges, or life-adjustment situations that come from biological development, social expectations, and personal action. These problems "change through life and give direction, force, and substance to . . . development." (Havighurst, 1973, p. 11).

Thus, the different developmental curves constitutive of lifelong development can be interpreted to reflect different developmental tasks. Some of these developmental tasks-like Havighurst's conception-are strongly correlated with age. However, as will be shown later, such developmental tasks are also constituted from certain historical and nonnormative systems of influence.

Multidimensionality and multidirectionality. The terms multidimensionality and multidirectionality are among the key concepts used by life-span researchers to describe facets of plurality in the course of development and to promote a concept of development that is not bound by a single criterion of growth in terms of a general increase in size or functional efficacy.

Research on psychometric intelligence illustrates the usefulness of multidimensional and multidirectional conceptions of development. The psychometric theory of fluid-crystallized intelligence proposed by Cattell (1971) and Horn (1970, 1982) serves as an example (Figure 1). First, according to this theory, intelligence consists of several subcomponents. Fluid and crystallized intelligence are the two most important clusters of abilities in the theory. The postulate of a system of abilities is an example of multidimensionality. Second, these multiple-ability components are expected to differ in the direction of their development. Fluid intelligence shows a turning point in adulthood (toward decline), whereas crystallized intelligence exhibits the continuation of an incremental function. This is an example of the multidirectionality of development.

Meanwhile, the Cattell-Horn theoretical approach to lifespan intellectual development has been supplemented with other conceptions, each also suggesting the possibility of multidimensional and multidirectional change. Berg and Sternberg (1985), for example, have examined the implications of Sternberg's triarchic theory of intelligence for the nature of life-long development. They emphasized that the age trajectories for the three postulated components of Sternberg's theory of intelligence (componential, contextual, experiential) are likely to vary in directionality.

Current work on life-span intelligence (Baltes et al., 1984; Dixon \& Baltes, 1986) has also expanded on the Cattell-Horn model by linking it to ongoing work in cognitive psychology. Two domains of cognitive functioning are distinguished in a dual-process scheme: the "fluid" mechanics and the "crystallized" pragmatics of intelligence. The mechanics of intelligence refers to the basic architecture of information processing and problem solving. It deals with the basic cognitive operations and cognitive structures associated with such tasks as perceiving relations and classification. The second domain of the dual-process scheme, the pragmatics of intelligence, concerns the context- and knowledge-related application of the mechanics of intelligence. The intent is to subsume under the pragmatics of intelligence (a) fairly general systems of factual and procedural knowledge, such as crystallized intelligence; (b) specialized systems of factual and procedural knowledge, such as occupational expertise; and (c) knowledge about factors of perfor- mance, that is, about skills relevant for the activation of intelligence in specific contexts requiring intelligent action. The explicit focus on the pragmatics of intelligence demands (like Sternberg's concern with contextual and experiential components) a forceful consideration of the changing structure and function of knowledge systems across the life span (see also Featherman, 1983; Keating \& MacLean, in press; LabouvieVief, 1985; Rybash et al., 1986).

New forms of intelligence in adulthood and old age? What about the question of later-life, "innovative" emergence of new forms of intelligence? It is one thing to argue in principle that new developmental acquisitions can emerge at later points in life with relatively little connection to earlier processes and quite another to demonstrate empirically the existence of such innovative, developmentally late phenomena. A classic example used by life-span researchers to illustrate the developmentally late emergence of a cognitive system is the process of reminiscence and life review (Butler, 1963). The process of reviewing and reconstructing one's life has been argued to be primarily a late-life phenomenon. The phenomenon of autobiographical memory is another example (Strube, 1985).

For the sample case of intelligence, it is an open question whether adulthood and old age bring with them new forms of directionality and intellectual functioning, or whether continuation and quantitative (but not qualitative) variation of past functioning is the gist of the process. On the one hand, there are Flavell's (1970) and Piaget's (1972) cognitive-structuralist accounts, which favor an interpretation of horizontal décalage rather than one of further structural evolution or transformation. These authors regard the basic cognitive operations as fixed by early adulthood. What changes afterwards is the content domains to which cognitive structures are applied.

On the other hand, there are very active research programs engaged in the search for qualitatively or structurally new forms of adult intelligence (Commons, Richards, \& Armon, 1984). The work on dialectical and postformal operations by Basseches (1984), Labouvie-Vief (1982, 1985), Kramer (1983), PascualLeone (1983), and other related writings (e.g., Keating \& MacLean, in press) are notable examples of this effort. This line of scholarship has been much stimulated (or even launched) by Riegel's work on dialectical psychology and his outline of a possible fifth stage of cognitive development (Riegel, 1973, 1976).

Other work on adult intellectual development proceeds from a neofunctionalist perspective (Beilin, 1983; Dixon \& Baltes, $1986)$ and is informed by work in cognitive psychology. Models of expertise (Glaser, 1984) and knowledge systems (Brown, 1982) guide this approach in which the question of structural stages is of lesser significance. Aside from an interest in the aging of the "content-free" mechanics of intelligence (Kliegl \& Baltes, in press), the dominant focus is on changes in systems of factual and procedural knowledge associated with the "crystallized" pragmatics of intelligence. The crystallized form of intelligence was highlighted already as an ability cluster exhibiting stability or even positive changes into late adulthood. The concept of crystallized intelligence, however, needs further expansion to cover additional domains of knowledge and to permit consideration of forms of knowledge more typical of the second half of life.

Expertise, a concept currently in vogue in cognitive and developmental psychology (Ericsson, 1985; Glaser, 1984; Hoyer, 
Multidimensionality Multidirectionality
Different Forms of Intelligence

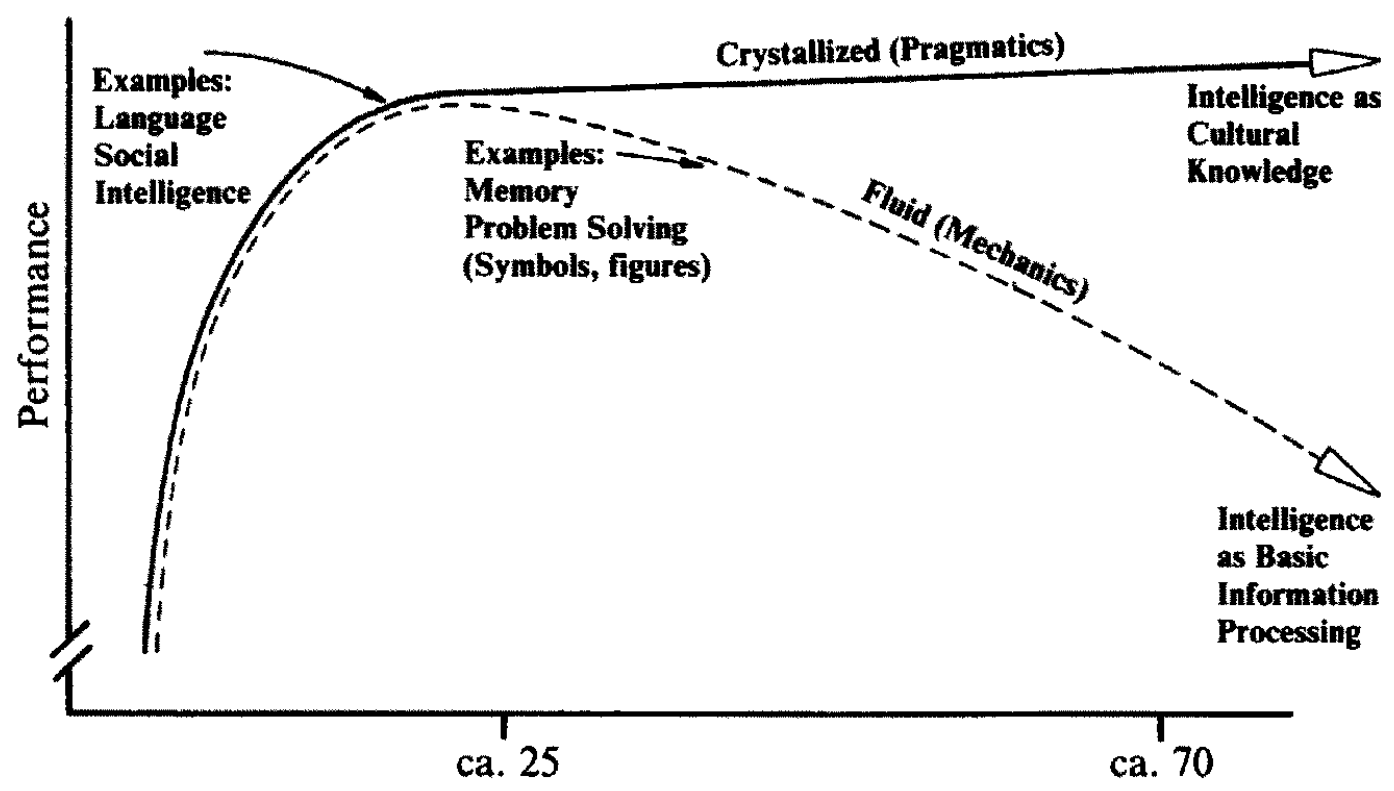

Age

Figure 1. One of the best known psychometric structural theories of intelligence is that of Raymond B. Cattell and John L. Horn. (The two main clusters of that theory, fluid and crystallized intelligence, are postulated to display different life-span developmental trajectories.)

1985; Weinert, Schneider, \& Knopf, in press), can be used to illustrate this avenue of research. This concept denotes skills and knowledge that are highly developed and practiced. The sciences, chess, or job-related activities (e.g., typing) are often used as substantive domains is which performance in relation to the acquisition and maintenance of expertise is studied. The life course of many individuals most likely offers opportunity for the practice of such forms of expertise. Therefore, one would expect that further growth of intellectual functioning may occur in those domains in which individuals continue to practice and evolve their procedural and factual knowledge (Denney, 1984; Dixon \& Baltes, 1986; Hoyer, 1985; Rybash et al., 1986). In other words, expertise in select facets of the pragmatics of intelligence can be maintained, transformed, or even newly acquired in the second half of life if the conditions are such that selective optimization in the associated knowledge system can occur.

Two areas of knowledge have been identified as key candidates for domains in which the pragmatics of intelligence may exhibit positive changes during the second half of life: practical intelligence (Sternberg \& Wagner, 1986) and knowledge about the pragmatics of life, such as is evident in research on social intelligence and wisdom (Clayton \& Birren, 1980; DittmannKohli \& Baltes, in press; Holliday \& Chandler, 1986; Meacham, 1982). Wistom, in particular, has been identified as a prototypical or exemplar task of the pragmatics of intelligence that may exhibit further advances in adulthood or whose origins may lie primarily in aduthood.
In one approach (Dittmann-Kohli \& Baltes, in press; Dixon \& Baltes, 1986; Smith, Dixon, \& Baltes, in press), wisctom is defined as an "expertise in the fundamental pragmatics of life." In order to capture wisdom, subjects of different age groups are asked, for example, to elaborate on everyday problems of life planning and life review. The knowledge system displayed in protocols of life planning and life review is scored against a set of criteria derived from the theory of wisdom. First evidence (Smith et al., in press) suggests, as expected by the theory, that some older adults indeed seem to have available a well-developed system of knowledge about situations involving questions of life planning. For example, when older adults are asked to explore a relatively rare or odd life-planning situation involving other alder persons, they demonstrate a knowledge system that is more elaborated than that of younger adults.

The study of wisdom is just beginning. Thus, it is still an open question whether the concept of wisdom can be translated into empirical steps resulting in a well-articulated psychological theory of wisdom. We are somewhat optimistic, inasmuch as cognitive psychologists are increasingly studying tasks and reasoning problems that, like the problems to which wistom is applied, have a high degree of real-life complexity, and whose problem definition and solution involve uncertainty and relativism in judgment (Dörner, in press; Neisser, 1982). In the present context, the important point is that research on wisdom is an illustration of the type of knowledge systems that developmental, cognitive researchers are beginning to study as their attention is focused on later periods of life. 


\section{Intellectual Development as a Dynamic Between Growth (Gain) and Decline (Loss)}

The next belief (see Table 1) associated with life-span work is the notion that any process of development entails aspects of growth (gain) and decline (loss). This belief is a fairly recent one and its theoretical foundation is not yet fully explored and tested.

The gain/loss argument. The gain/loss view of development emerged primarily for 1 wo reasons. The first relates to the task of defining the process of aging in a framework of development. The second reason deals with the fact of multidirectionality described earlier and the ensuing implication of simultaneous, multidirectional change for the characterization of development.

Concerning the issue of the definition of aging versus development: Traditionally in gerontology, there has been a strong push-especially by biolagists (Kirkwood, 1985) - to define the essence of aging as decline (i.e., as a unidirectional process of loss in adaptive capacity). Behavioral scientists, because of their findings and expectations of some gains in old age, have had a tendency to reject this unidirectional, decline view of aging. Thus, they wanted to explore whether aging could be considered as part of a framework of development.

How could this integration of aging into the framework of development be achieved in light of the fact that the traditional definition of development was closely linked to growth, whereas that of aging was linked predominantly to decline? The suggestion of life-span researchers was to redefine or expand the concept of development beyond the biological conception of growth or progression. Specifically, the proposal was to expand the concept of development to include not only phenomena of growth (gain), but other directions of change as well (Baltes, 1983). As a result, development was defined as any change in the adaptive capacity of an organism, whether positive or negative. In developmental psychology, this proposal was consistent with other trends. Social learning theory, for example, had suggested a similar expansion of the directional nature of ontogenesis (Bandura, 1982).

The second and related reason for the emergence of the theme of gain-loss relations in development is a further elaboration of the notions of multidimensionality and multidirectionality of life-span intelligence. The separate concern for multiple-ability systems associated with multidirectionality was taken one step further to the examination of the relation and perhaps even the dynamic interplay between the various subsystems. The question guiding this investigation is whether the occurrence of multidirectional change, concurrently in separate components of the system (c.g., fluid vs. crystallized intelligence), requires a new conception of development itself. One possible avenue is to view development as a gain-loss relation (see also Baltes \& Kliegl, 1986; Labouvie-Vief, 1980, 1982; Perlmutter, in press). According to this view, development at all points of the life course is a joint expression of features of growth (gain) and decline (loss). It is assumed that any developmental progression displays at the same time new adaptive capacity as well as the loss of previously existing capacity. No developmental change during the life course is pure gain.

The view of development as a gain/loss phenomenon, of course, does not imply that throughout life gain and loss exist

\section{Life-span Development: Gain/Loss Ratios in Adaptive Capacity}

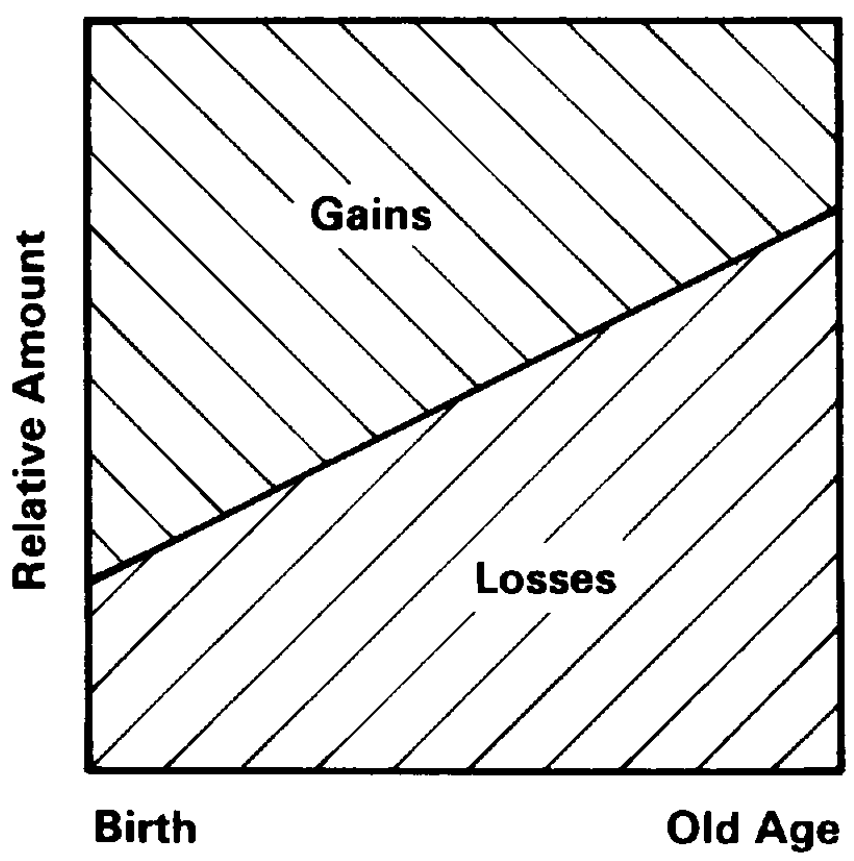

Figure 2. One theoretical expectation concerning the average course of gain/loss ratios is a proportional shift across the life span.

in equal strength. Systematic age-related changes in the gain/ loss proportion are likely to be present. A possible life-span scenario of the dynamic between gains and losses is illustrated in Figure 2. Summarizing evidence across a wide spectrum of functions, the proposition contained in Figure 2 is that the sum total of possible gains and losses in adaptive capacity shifts proportionally with increasing age. As a whole, life-span development proceeds within the constraints created by this dynamic.

The concern with an ongoing, developmental dynamic of positive (gains) and negative (losses) change has spurred new research in life-span work. One example is the attempt to specify a general process of adaptation that would represent the lifelong nature of development as a gain/loss relation. Some of this work (M. Baltes, 1987; Baltes et al., 1984; Dixon \& Baltes, 1986) has outlined a theoretical framework that is aimed at making explicit the dynamic relation between gain and loss in development. In Table 2 , what is described for the case of cognitive aging is perhaps a prototypical change mechanism of "successful aging"-selective optimization with compensation.

The process af selective optimization with compensation has three features, each indicative of a gain/loss relation: (a) continual evolution of specialized forms of adaptation as a general feature of life-span development; (b) adaptation to the conditions of biological and social aging with its increasing limitation of plasticity; and (c) individual selective and compensatory efforts dealing with evolving deficits for the purpose of life mastery and effective aging.

Although the process of selective optimization and associated investments in terms of time, space, and behavior budgeting is assumed to be general and prototypical, its specific manifesta- 
Table 2

Selective Optimization With Compensation: A Process Prototypical of Adaptive Life-Span Development of Cognitive Functioning

- A general feature of life-span development is an age-related increase in specialization (selection) of motivational and cognitive resources and skills.

- There are two main features of the aging of cognitive functions: (a) The reserve capacity for peak or maximum performances in fluid functioning (mechanics of intelligence) is reduced.

(b) Some procedural and declarative knowledge systems (pragmatics of intelligence) can continue to evolve and function at peak levels.

- When, and if, limits (thresholds) of capacity are exceeded during the course of aging for a given individual, the following developmental consequences result:

(a) Increased selection (channeling) and further reduction of the number of high-efficacy domains

(b) Development of compensatory and/or substitute mechanisms.

Note. This model is adapted from Baltes and Baltes (1980).

tion will vary depending on the individual life history. The emergence of compensatory and substitutive cognitive skills will also vary. For example, B. F. Skinner (1983) described in a personal account how and under which conditions he evolved compensatory or substitutive skills in the face of reduced effectiveness in select aspects of intellectual functioning.

Research by Salthouse (1984) on typing skills in old age is one persuasive example of how specialization and compensation interact in older adults to produce a high level of selective efficacy. Older expert typists-although showing less efficient reaction times than young expert typists when confronted with the typing of individual characters--nevertheless display good efficacy. They cope with their loss in reaction time when typing individual letters by developing more extensive forward-processing of letter and word sequences. As a result, older typists use a different combination of component skills than younger typists to produce a comparable level of overall performance.

Relevance of the gain/loss argument for other developmental questions. For historians interested in the study of social change and the idea of progress (Nisbet, 1980), the gain/loss argument is a truism. Few theorists would maintain that all of social change is progress.

What about ontogenesis? The notion that any ontogenetic change entails a dynamic interplay between gain and loss can be found also in biological conceptions such as Waddington's (1975) work on ontogenesis as differentiation and specialization (canalization). Beginning on the cellular level (Cotman, 1985; Lerner, 1984), differentiation clearly implies the loss of alternate courses of cell differentiation. Sociologists, too, have argued that the life course entails a process of specialization in the sense of commitment to and practice in selected domains of life (Featherman, 1983). Such a process of life-course specialization is assumed to imply a loss of alternative options.

Does the consideration of gains and losses as intrinsic to any developmental process have relevance for cognitive development in younger age groups? The fact that progress is not the only feature of age-related cognitive development has been known for quite some time. Weir's (1964) research with chil- dren on the developmental progression from maximization to optimization strategies in solving nonperfect probability tasks is a concrete example. This work shows that higher-level cognitive functioning (associated with the so-called optimization strategy) can have its costs when the task in question has no perfect solution. Specifically, when a cognitive task is logically unsolvable, because it has no perfect solution, young children can outperform older children and adults. This is so because older children and adults assume the existence of a logically perfect solution and, therefore, engage in a problem-solving behavior that is criterion-inadequate.

One additional example is Ross's (1981) research on the development of judgmental heuristics. Developmentally later or more "mature" heuristics can be less efficient, depending on the problem to be solved. Another case is second-language learning. Although there is disagreement about the sources of this gain/ loss phenomenon, the fact seems accepted: The more and more efficient acquisition of a first language is associated with increasing difficulty in learning a second language (Davies, Criper, \& Howatt, 1984; Kellerman \& Smith, 1986).

The gain/loss idea is also contained in the work of Piaget, even though Piagetian theory is likely seen by most as the hallmark of a conception of development that features unidirectional growth. In the study of the age-development of visual illusions, for example. Piaget (1969) described illusions that increase with age and others that decrease with age. When visual illusions increase with age, Piaget ascribed this loss in visual accuracy to advancement in cognitive stage. A related example in Piaget's work (see Chapman, in press) is what he called the "repression" effect associated with a dynamic between perceptual and cognitive operations. With children of 7 to 8 years of age, Piaget found that their "veridical" perceptual knowledge was repressed by the (in this case, nonveridical) advancement in conceptual schemata. In effect, cognition "repressed" perception. A by-product of cognitive advancement, then, was a loss in veridical judgment involving perception.

It seems worthwhile to explore with greater force the idea that any process of cognitive development entails positive and negative aspects of change in adaptive capacity. In the long run, the treatment of this question is likely to be tied to the topic of adaptive fitness. In other words, as is true for evolutionary theories (as exemplified in the work of Gould and Lewontin [Lerner, 1984]), ontogenesis may not fundamentally be a process of general gain in the sense of a total increase in adaptive efficacy. As specific forms of mind and behavior are "selected" during ontogenesis for activation and growth, some adaptive capacities may actually become reduced. Whether the reduction is manifest would depend (as is true for evolutionary change) on the criterion demands posed by the individual and the environment in subsequent phases of life, or by the experimenter for that matter.

\section{Plasticity of Development}

Another belief (Table 1) held by many life-span scholars is that there is much plasticity in the course of life-span development. Plasticity refers to within-person variability and designates the potential that individuals have for different forms of behavior or development (Gollin, 1981; Lerner, 1984). Would the same individual develop differently if conditions were 
different? The question of plasticity is, of course, one that has excited developmental psychologists for a long time (e.g., McGraw's [1985] work in the 1930s on motor development in identical twins). It is of equal interest to current work in developmental biology (e.g., Cotman, 1985) and developmental sociology (Dannefer \& Perlmutter, 1986; Featherman \& Lerner, 1985).

Cognitive training research with the elderly. Whether it proves to be true, the conclusion that the plasticity of cognitive age differences found in the second half of life is larger than what is known from childhood research has impressed life-span researchers. The salience of the topic of plasticity for researchers in life-span development and the general approach used to study it can be illustrated easily in work on intellectual development during adulthood and old age. Initially, in life-span research the idea of plasticity was promulgated in connection with the question of whether intellectual aging is a simple process of gradual decline (Baltes \& Schaie, 1976; Horn \& Donaldson, 1976). One of the attractive ways to explore this question was to conduct intervention research.

Since the early 1970 s, various research programs have been underway to examine the extent to which the observed aging losses in that cluster of psychometric intelligence evincing most definite decline - fluid intelligence-could be simulated for by performance variation (plasticity) within individuals. For example, elderly people were given practice in solving the type of intelligence problems used to measure fluid intelligence (Baltes \& Kliegl, 1986; Willis, 1985). The key research hypothesis was that older persons, on the average, have relatively little test experience and everyday practice in fluid intelligence, but that they possess the reserve-the latent competence- to raise their level of performance on fluid intelligence tasks to that of younger adults.

The cognitive training research conducted with older adults offered strong evidence of sizeable plasticity. After a fairly brief program of cognitive practice, many older adults (age range, 60-80 years) exhibited levels of performance comparable with those observed in many "untreated" younger adults. Such findings have been replicated consistently and in other domains of cognitive functioning (e.g., Denney, 1984; Labouvie-Vief, 1985; Willis, 1985). Meanwhile, the evidence has been extended from cross-sectional to longitudinal age comparisons (Schaie \& Willis, 1986).

These studies illustrate the emergence of the strong belief of life-span researchers in sizeable plasticity. Knowledge about plasticity of intelligence was judged to be as important as knowledge about the average course of age development. In order to achieve a comprehensive understanding of a given developmental process, such as intellectual development, one must forcefully advance the study of conditions that produce differences in development and highlight the potential for alternate courses of development. The resulting interpretative posture is that whatever one observes concerning the aging of intelligence is but one of many possible outcomes (Brandtstädter, 1984; Lerner, 1984). Knowing the range and limits of intraindividual functioning, therefore, is a cornerstone of the life-span perspective.

From plasticity to limits of plasticity. Current work on plasticity of life-span intellectual development has added new perspectives beyond those associated with cognitive training re- search. The focus has changed from demonstration of plasticity toward using research on plasticity as a strategy by which limits and boundaries of development can be identified (Kliegl \& Baltes, 1987). This strategy is similar to child research on the "zone" of proximal development in childhood (Brown, 1982; Ferrara, Brown, \& Campione, 1986).

The resulting focus in the life-span study of plasticity is not on the normal range of intellectual functioning, but on limits of performance. The research strategy chosen to examine different aspects of plasticity and its boundary conditions is known as testing-the-limits (M. Baltes \& Kindermann, 1985; Guthke, 1982; Wiedl, 1984). Testing-the-limits involves the systematic application of (a) variations in modes of assessment, (b) methods of intervention aimed at identifying latent reserve capacity, and (c) strategies of identification of the mechanisms involved in growth and decline.

In our research efforts (Baltes et al., 1984; Kliegl \& Baltes, 1987 ) intended to determine age-correlated changes in limits of intellectual functioning, three aspects of plasticity are distinguished: (a) baseline performance, (b) baseline reserve capacity, and (c) developmental reserve capacity. Baseline performance indicates a person's initial level of performance on a given task, that is, what a person can do in a specified task without intervention or special treatment. Baseline reserve capacity denotes the upper range of an individual's performance potential, when, at a given point in time, all available resources are called on to optimize an individual's performance. It is measured by tests of "maximum" performance. When conditions have been added that strengthen an individual's baseline reserve capacity through intervention (or development), we speak of an individual's developmental reserve capacity.

Distinguishing between these three aspects of plasticity permits the study not only of plasticity but also of constraints (Keil, 1981) and of what behavior geneticists have called the norm of reaction (see Lerner, 1984). Concepts such as constraint and norm of reaction are intended to index those limits-biological and sociocultural-that restrict the formation of a given behavior and its open development. In the long run, assessment of maximum reserve capacity aspires to identify biological boundaries of the plasticity of development. Note, however, that the range and level of maximum reserve capacity is inherently unknowable (see also Keating \& MacLean, in press); it can only be approximated. The possibility always exists that new conditions or agents may be found that produce new levels and forms of intellectual performance on a given task.

The general expectation of testing-the-limits research is to predict developmental differences to be most pronounced, perhaps even approaching the condition of irreversibility (Wohlwill, 1973), near maximum levels of performance. Conversely, age changes are easily masked or modified as long as they are studied within the "normal" range of functioning. Figure 3 illustrates how a testing-the-limits strategy is used to obtain information about the range and limits of plasticity during adulthood.

The data presented in Figure 3 are based on subjects of different adult age groups who participated in extensive longitudinal intervention studies. In these studies, high levels of cognitive functioning in the use of a mnemonic skill are engineered in the laboratory. Specifically, subjects participated in $\mathbf{3 0}$ sessions of training of expert memory for digits and nouns using the Method 


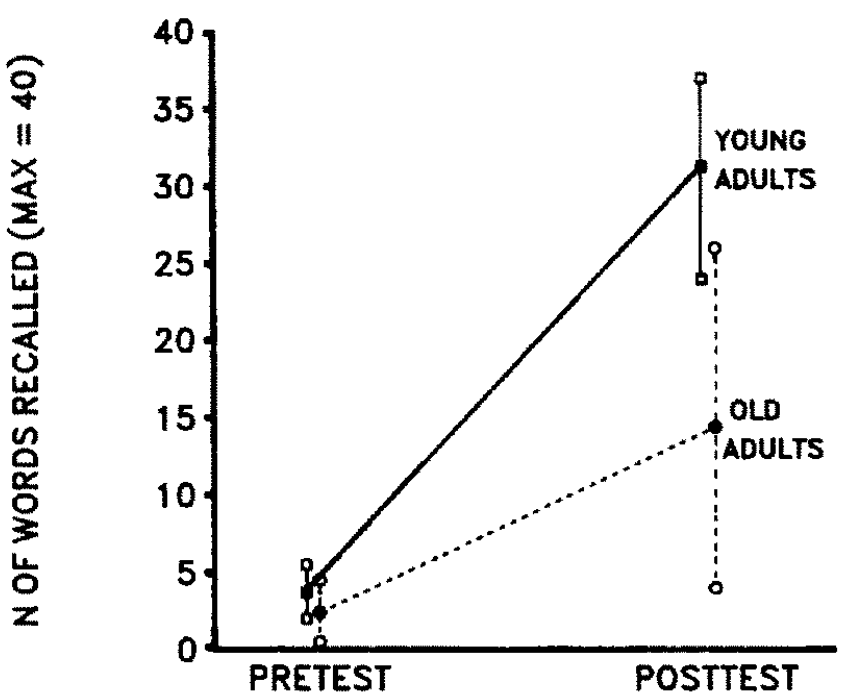

Figure 3. Expertise in Method of Loci: Mean and range of recall for 40 words in two subject groups of young and old adults (for data on digit span, see Klicgl, Smith, \& Baltes, 1986).

of Loci (Kliegl, Smith, \& Baltes, 1986; Smith, Kliegl, \& Baltes, 1987). The results demonstrate, as expected, the dual nature of results from application of testing-the-limits methodology. On the one hand, sizeable plasticity continues to be evident into old age. The reserve capacity is substantial in all age groups, so that subjects of all ages can leam to remember exceedingly long strings of numerical digits and nouns. On the other hand, pronounced age differences in limits also exist. When subjects are tested under more and more difficult conditions, such as with increased speed of presentation, age differences are magnified. In the present example, the magnification of age differences is of such a degree that, at "limits" 1Q-comparable young and older subjects barely overlap in their performance.

With such research on the limits of development, the concern for plasticity has taken a new turn. The task is no longer to focus on the demonstration of plasticity as a sole feature of development. Rather, the search is simultaneously for potential (reserve capacity) and constraints. Testing-the-limits research has a braad range of ramifications. It is not only relevant for the study of istellectual development and aging; its possible usefulness also extends to many other fields of study. Consider the study of behavioral and developmental genetics. A possible view is that the role of genetics in regulating interindividual differences can be best examined when the investigation is focused on limits of performance. Another example is the identification of developmental dysfunctions. Like the stress tests used in biology and medicine (M. Baltes \& Kindermann, 1985; Coper, Jänicke, \& Schulze, 1986; Fries \& Crapo, 1981), psychological tests conducted under conditions of high difficulty or following testingthe-limits-like interventions are likely to be more sensitive to the detection of dysfunctions (such as depression, senile dementia of the Alzheimer type, or reading difficulty) than testing under conditions of the normal range of demand and expertise.

Development Is Codetermined by Multiple Systems of Infuence

The fifth and sixth belief systems (historical embeddedness, contextualism) associated with life-span research have ex- panded the spectrum of influences that are considered determinants of behavioral development. A new taxonomy of influence systems has evolved that entails factors beyond the ones considered in past work on psychological ontogeny.

Ontogenesis and evolution. The perspective of historical embeddedness deals with the relation between individual development (ontogenesis) and evolutionary development (Baltes, 1983; Brent, 1978; Dannefer. 1984; Featherman \& Lerner, 1985; Nesselroade \& von Eye, 1985; Riegel, 1976). The processes of individual development are governed both by principles of ontogenesis and by factors associated with the concurrent process of biocultural change. Together, ontogenesis and biocultural change constitute the two major systems generating development. As individuals develop, society changes as well.

The role of a changing society in codetermining individual development initially came to the forefront in life-span research on cohort differences (Baltes, 1968; Riley et al., 1972; Schaie, 1965); later, its significance was amplified because of theoretical issues such as dialectics and contextualism (Lerner, 1984; Lerner \& Kauffman, 1985; Riegel, 1976). In research on cohort effects, the age-development of several birth cohorts is studied in a comparative manner. The basic designs are known as crosssectional and longitudinal sequences. An excellent up-to-date review of design and analysis of cross-sectional and longitudinal sequences is presented by Labouvie and Nesselroade (1985).

Life-span research with sequential methods has been conducted with many age groups, cohorts, and measurement systems (see Battes, Comelius, \& Nesselroade, 1979, and Nesselroade \& von Eye, 1985, for review). The empirical story began in the periods of adulthood and old age and subsequently extended into earlier segments of the life span. In adulthood and old age, Schaie $(1979,1983)$ could show that much of the variance contained in cross-sectional studies of age differences in adult intelligence is associated with historical cohort factors rather than age factors.

In adolescence, Nesselroade and Baltes (1974) obtained data that showed that the level and direction of change in adolescent personality development was as much influenced by the historical context (in this case surrounding the Vietnam War) as by age-associated factors. Elder's (1974; Elder \& Liker, 1982) work on the life-span development of children and adolescents stemming from the period of the Great Depression offered clear evidence of the impact of historical factors associated with childhood on adult personality.

With respect to infancy, Porges (1976) argued that much of the controversy about conditionability of neonates may be due to historical changes in prenatal and postnatal care. Since then, the possible impact of cohort variation has been explored in a variety of other areas related to infant and child development, including the structure and function of family systems such as the changing characteristics of fatherhood (Parke \& Tinsley, 1984).

In the present context, Schaie's 28-year cohort-sequential study on adult intelligence is particularly relevant. In Schaie's (1979, 1983) data, the historical embedding of intellectual development is paramount. Intelligence does not only change with age. It also changes with history or cohort time. Consider, for instance, 50 - or 60 -year-olds. Cohort differences between these two age levels can be as large as longitudinal aging changes within the same subjects (Schaie, 1983). In Figure 4, such co- 


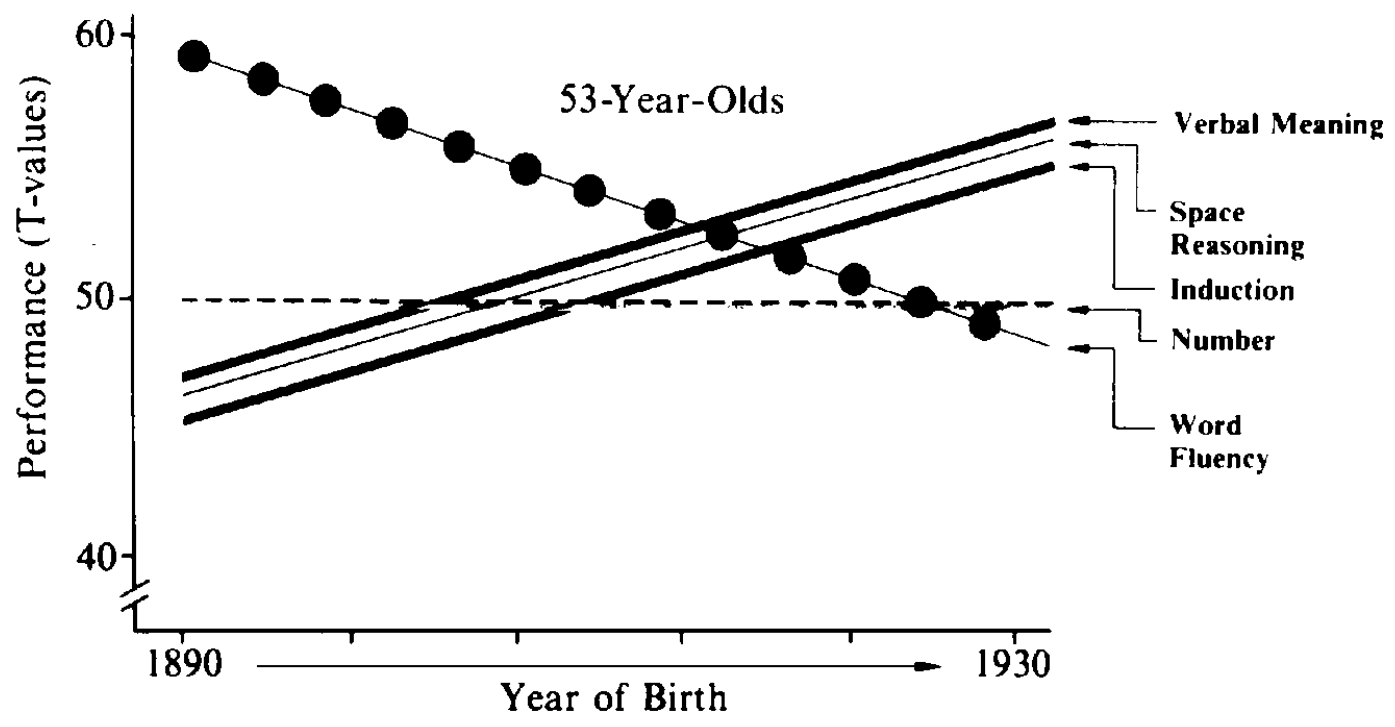

Figure 4. Historical, cohort changes in intellectual performance concern level of functioning as well as directionality. (The simplified trends represent the average perfor mance of 53-year-olds from different birth cohorts on five measures of primary mental abilities, as estimated by Schaie [1979] on the basis of time-lag comparisons.)

hort-related changes in same-age individuals are illustrated for a larger range of birth cohorts based on Schaie's (1983) work. For one age group-53-year-olds-levels of performance are estimated and plotted in a simplified manner separately for the five primary mental abilities studied (number, reasoning, space, verbal meaning, and word fluency). Three of the five abilities show positive historical change; one is cohort-invariant; the fifth evinces negative change with historical time. Changes in intelligence, then, are multidirectional not only with chronological age but also with historical time.

Cohort effects of the magnitude reported in studies of adult intelligence are novel in psychological research. Therefore, it is not surprising that classical psychological theory has little to offer when it comes to interpreting the substantive meaning and origin of such cohort effects (see, however, Dannefer, 1984; Featherman \& Lemer, 1985; Riley, 1985). The fields of cultural anthropology, historical sociology, and historical medicine may prove to be more relevant.

Three clusters of influences appear to be primarily involved as origins of cohort effects in life-span development of intelligence: education, health, and work. Successive generations, for example, exhibit, on the average, more formal education and other kinds of education-related experiences, such as those associated with the introduction of television or computers. The work life of recent generations may also entail, on the average, a stronger and differential focus on cognitively oriented labor. Furthermore, historical changes have occurred in health care, including, for example, the better treatment of hypertension, a factor implicated in lowered intellectual functioning among the elderly. Together, these examples indicate that many facets of the texture of everyday life exhibit sociocultural change possibly related to the level and rate of intellectual functioning. At present, however, the factors responsible for the cohort changes observed in intellectual aging have not yet been specified.

In summary then, results from cohort-sequential research on intelligence during adulthood and old age suggest much variability in the level and course of intellectual aging. Part of the nature of the reported findings is that they cannot be generalized to other cultural settings and historical epochs. But this feature of research on the aging of intelligence is at the very core of the argument: Depending on the prevailing cultural conditions, the level and course of intellectual aging can vary markedly. Any single cohori-specific observation does not tell the final story on the nature of intellectual aging.

Are cohort differences and biocultural change always relevant for the study of psychological development? Most likely they are not. Cohort differences are more likely to be a concern for those aspects of development that are not stabilized in the process of genetic and cultural evolution. Thus, it is not surprising that in developed countries, because of the high degree of biocultural stabilization in early life, cohort variation in cognitive development during childhood is relatively small and primarily involves differences in rate (Kendler, 1979; Reese, 1974).

Because cohort differences can have rather different empirical and theoretical significance, Baltes, Cornelius, and Nesselroade (1979) have distinguished among several ways in which cohort variation can be treated in developmental psychology (e.g., as error, historical disturbance, quantitative variation in frequency and rate, or as a theoretical/dialectical process). On the basis of this theoretical analysis of cohort effects, it is recommended that researchers examine carefully which logical stalus they are prepared to assign to cohort effects. Such a decision will influence the way cohort-sequential research is designed and ensuing data are analyzed.

Other contextual factors and contextualism. In life-span work, the argument for the historical embeddedness of human development was joined by another facet of embeddedness involving additional classes of contextual influences. Historically, the emerging focus on life events (Bandura, 1982; Brim \& Ryff, 1980; Dohrenwend \& Dohrenwend, 1974; Filipp, 1981; 
Hultsch \& Plemons, 1979) was the initial forum for dialogue about such additional contextual factors and their role in human development. It was proposed that the course of adult development is not only dependent on age-correlated factors of socialization. Rather, "significant" live events-with rather distinct patterns of individual occurrence and sequencing-were identified as important regulators of the nature of change during adulthood.

An additional reaction to the evidence on cohort effects and the role of other contextual factors was metatheoretical. Following the lead of Riegel $(1973,1976)$ and the concurrent emergence of interest in Marxist and Hegelian thought (Datan \& Reese, 1977), life-span psychologists began to proffer a metatheoretical view of development that was inherently dialectical and contextual (Dixon, 1986; Featherman \& Lerner, 1985; Labouvie-Vief \& Chandler, 1978; Lerner \& Kauffman, 1985). In its radical form (Gergen, 1980), the metatheoretical argument was that ontogeny, in principle, is not universal. Rather, the nature of psychological ontogeny is always newly created for any given birth cohort or cultural setting.

Meanwhile, this radical view has given way to more moderate but also more refined positions (Dannefer, 1984; Featherman \& Lerner, 1985; Lerner \& Kauffman, 1985). Note, however, that the metatheoretical argument associated with contextualism in life-span developmental psychology is not necessarily synonymous - on a theoretical level - with the general advancement of an ecological approach evident in other developmental scholarship. Bronfenbrenner (1977) surely emphasized context. His conceptualization of context, however, does not explicitly follow the metatheoretical principles of contextualism. The metatheoretical guidelines of contextualism, for instance, suggest a general conception of development, which Lerner and Kauffman (1985) have called dynamic and probabilistic interactionism. That a focus on the same notion (such as the role of context) does not imply an identical metatheoretical treatment is illustrated in the exchange between Kendler (1986) and Lerner and Kauffman (1986).

A taxonomy of influences. The preceding discussion of interindividual variability and cohort effects and other contextual factors points toward a search for a new conception of developmental influences. The strategy chosen by life-span researchers is to argue that pluralism and complexity in the descriptive form of development is paralleled by a certain pluralism and complexity in the causal scheme of developmental factors and mechanisms.

For the heuristic purpose of organizing the multitude and complexity of developmental influences, a trifactor model has been proposed (Baltes et al., 1979; Baltes et al., 1980). In this model, three categories of influences, which developing individuals need to deal with (i.e., process, react to, act on) as their lives progress, are identified: age-graded influences, history-graded influences, and nonnormative influences. These three influences operate throughout the life course, their effects accumulate with time, and, as a dynamic package, they are responsible for how lives develop.

Age-graded influences are identical to what most child psychologists and gerontologists have considered the major source of influence on development. They are defined as those biological and environmental determinants that (a) have a fairly strong relation with chronological age and are therefore fairly predict- able in their temporal sequence (onset, duration), and (b) are, for the most part, similar in their direction among individuals. Biological maturation and age-graded socialization events are examples of age-graded influences.

History-graded influences also involve both biological and environmental determinants. These influences, however, are associated with historical time (Elder, 1985; McCluskey \& Reese, 1984; Neugarten \& Datan, 1973; Riley et al., 1972) and define the larger evolutionary, biocultural context in which individuals develop. Two types of history-graded influences are likely to exist: those that evince long-term change functions (e.g., toward modernity), and others that are more time or period-specific (e.g., war).

Nonnormative influences also include both biological and environmental determinants (Bandura, 1982; Callahan \& McCluskey, 1983; Filipp, 1981). Their major characteristic is that their occurrence, patterning, and sequencing are not applicable to many individuals, nor are they clearly tied to a dimension of developmental time, whether ontogenetic or historical. Nonnormative influences do not follow a general and predictable course.

The trifactor model is easily misunderstood in two respects. First, it may be seen as static. The intent, rather, is to emphasize temporal dynamics (the systems themselves are not historically invariant) and the notion that codeveloping individuals (such as grandparents, parents, and children; Tinsley \& Parke, 1984) participate in different segments of the streams of influences. Second, the model may suggest that its focus is more on "normative," average regularities in development than interindividual differentiation. It is important to note, therefore, that systematic interindividual differences exist within each of the categories. In an exchange with Dannefer (1984), for example, Baltes and Nesselroade (1984) emphasized that macrostructural processes of stratification (related to sex, social class, ethnicity, etc.) are associated with clear-cut patterns of individual differences within the stream of age-graded, history-graded, and nonnormative influences.

Some of the influences identified in life-span models, particularly the age-graded ones, result in interindividual similarity in the direction of development. They are the basic components of those classic ontogenetic theories that have been associated with physical maturation and age-graded socialization, such as Piaget's theory of cognitive development, or Freud's theory of psychosexual development. The second category of influences, those that are history-graded, compounds the variability of human development through the impact of historical changes on the course of life-span development. The third category of influences, the nonnormative, renders the individuality or idiosyncracy of behavioral development most apparent.

In summary then, life-span researchers focus on complex and pluralist explanations of behavioral development. From the recognition of the historical embeddedness of development and the finding of sizeable individual variability in the nature of aging, they have joined other developmental researchers in the recognition of contextual factors and the unique combination of influences that shape a given life course. Some life-span researchers (e.g., Dixon, 1986; Lerner \& Kauffman, 1985) have gone beyond the identification of the important role of contextual factors and pushed forcefully in the direction of elevating at least a version of the paradigm of contextualism as the primary 
metatheoretical avenue for understanding the nature of human development.

\section{Child Intellectual Development in Life-Span Perspective}

Concern for the family of perspectives advanced by life-span researchers (as expressed, for instance, in the following concepts: multidimensionality, multidirectionality, gain/loss dynamic, plasticity, and contextualism) has not been as strong on the part of cognitive-developmental researchers concerned with earlier segments of the life span. Aside from the possibility that this evaluation is wrong (Scarr, 1986), there may be a good reason. The data suggest that, in the early phases of the life span, cognitive change toward an increasingly "mature" organism occurs with much regularity. In contrast to the overall regularity surrounding the earlier portion of the life span (McCall, 1979), adulthood and old age are characterized by more openness, variability, and plasticity.

One possible interpretation of this difference between findings on childhood and adulthood locates the origins for this difference in the macro-context surrounding human development. In adulthood and old age, biological and cultural stabilization is less apparent. The biocultural dynamics shaping adulthood and old age are of fairly recent origin and fluctuate in a manner that permits a fair degree of change and active control by the developing individual (Dixon \& Baltes, 1986). Conversely, in childhood, biological and societal conditions have converged to form a relatively more solid fabric of influences that generates regularity.

This possible life-span difference in the relative degree of stability of developmental influences has led Baltes et al. (1980) to consider the existence of a general profile of the varying, relative importance of the three types of influences (age-graded, history-graded, nonnormative) through the life course. The argument advanced suggested that, on the average, age-graded influences may be the most pronounced in childhood. This is perhaps the reason why developmental psychologists interested in infancy and childhood have focused in their research and theory foremost on developmental conceptions that entail agegraded changes, factors, and mechanisms. History-graded and nonnormative factors, on the other hand, may gain in prominence as individuals move beyond childhood.

\section{On Multidisciplinary Conceptions of Development}

The multitude of influences forming a framework for the origins and directionality of life-span development and its variations also makes explicit why life-span researchers believe so strongly that any single-discipline account of behavioral development is incomplete. The sources of and the mechanisms associated with age-graded, history-graded, and nonnormative influences do not lie within the scientific province of a single discipline such as psychology. History-graded influences, for example, are difficult to approach with psychological concepts and methodology.

An in-depth articulation of the conceptual nature of multidisciplinary connections in the study of life-span development is beyond the scope of this article (see Featherman, 1983). A minimum understanding of other disciplines is mandatory for a number of reasons. First, a multidisciplinary perspective helps one to appreciate the incompleteness of any discipline's theory of behavioral development. Psychologists, for example, study vocational interests and career development; sociologists and economists, however, are ready to point out that these phenomena are influenced by social stratification and the conditions of the labor market. Similarly, psychologists investigate parentchild relationships, but family sociologists point to the important role of historical changes in defining family structure and functioning, including aspects of household structure and fertility patterns.

Second, interdisciplinary work is more than the mere recognition of the incompleteness of one's own discipline and the strength of other disciplines. The quest is also for interdisciplinary efforts in the sense of integration of knowledge, as opposed to the separatist differentiation of disciplinary knowledge bases. The life-span perspective offers a unique opportunity as a forum for transdisciplinary integrative efforts. Elder's (1974; Elder \& Liker, 1982) work on the relation between conditions of history (e.g., economic depression) and personality development is an example, as is Featherman and Lerner's (1985) recent effort to link sociological with psychological perspectives in arriving at a new conception of development.

\section{Retrospect and Prospect}

Life-span developmental psychology is presented not as a theory, but as a theoretical perspective. As a perspective, the lifespan view coordinates a number of substantive, theoretical, and methodological principles about the nature of behavioral development. Although none of these principles is new, the variation in the strength of the beliefs and the kind of emphasis and coordination contributes uniqueness and novelty.

Essays on historical and theoretical developments in developmental psychology are bound to be somewhat egocentric, topiccentric, and data-centric, to name but a few of the possible centrisms. The field of developmental psychology is more complex and rich than is expressed in this article, where the life-span approach was occasionally juxtaposed with putative theoretical emphases in other fields of developmental specialization. In this respect, the present article surely is an oversimplification.

Having taken the avenue of summarizing what is innovative and possibly useful about the metatheoretical beliefs of lifespan developmental psychology, the following observations are offered, both as self-protective disclaimer and as an effort toward achieving better communication between life-span scholars and other developmentalists. Not unlike the gain/loss argument advanced as characteristic of any process of development, the family of beliefs presented here as prototypical of life-span developmental psychology has its dangers and costs. First, there is the question of scientific imperialism. In this sense, life-span scholars are occasionally regarded as holding the opinion that nothing but a life-span view is acceptable (Kaplan, 1983; Sears, 1980). To conclude that the theoretical propositions on the nature of development advanced here have been invented by lifespan scholars or to proffer life-span developmental psychology as the royal road of developmental psychology or as the superior approach would be inappropriate. Life-span developmental psychology is but one of the many specializations in developmental scholarship.

Second, there is the issue of theoretical overload. The contri- 
butions to metatheory and metamethodology offered by lifespan developmental researchers are important. What metatheoretical discourse can achieve, however, is limited. For example, enlarging and opening up the concept of development has its costs, especially if one or the other of the family of perspectives is taken to its extreme (Baltes, 1983; Lerner, 1984; Montada, 1979). As for plasticity, for a few years the emerging position on intellectual aging was one of complete openness, rather than plasticity within a set of constraints. Similarly, the issue of cohort effects was occasionally taken to a posture of full-blown dialectics or historicism, as if there were no regularity to development at all (for a critical evaluation, see Montada, 1979; Scholnik, 1985). Third, life-span researchers disproportionately emphasize adulthood rather than childhood, yet no strong psychology of life-span development can exist without solid research on earlier phases of life.

Such criticisms, putting life-span developmental psychology and life-span developmentalists into jeopardy, are serious. One approach to these dangers is to call for more intellectual modesty and more communication between the different quarters of developmental research (see also Hetherington, Lerner, \& Perlmutter, in press). If we achieve such communication without unnecessary irritation, the future of the life-span approach is likely to be productive. Otherwise, life-span developmental psychology will be not only an edifice without a foundation, but also a network of scholars without partners.

\section{References}

Baltes, M. M. (1987). Erfolgreiches Altern als Ausdruck von Verhaltenskompetenz und Umweltqualität [Successful aging as a function of behavioral competence and environmental quality]. In C. Niemitz (Ed.), Der Mensch im Zusammenspiel von Anlage und Umwelt (pp. 353-376). Frankfurt, West Germany: Suhrkamp.

Baltes, M. M., \& Kindermann, T. (1985). Die Bedeutung der Plastizität für die klinische Beurteilung des Leistungsverhaltens im Alter [The significance of plasticity in the clinical assessment of aging]. In D. Bente, H. Coper, \& S. Kanowski (Eds.), Hirnorganische Psychosyndrome im Alter: Vol. 2. Methoden zur Objektivierung pharmakotherapeutischer Wirkung (pp. 171-184). Berlin: Springer Verlag.

Baltes, P. B. (1968). Longitudinal and cross-sectional sequences in the study of age and generation effects. Human Development, $11,145-$ 171.

Baltes, P. B. (1983). Life-span developmental psychology: Observations on history and theory revisited. In R. M. Lerner(Ed.), Developmental psychology: Historical and philosophical perspectives (pp. 79-111). Hillsdale, NJ: Erlbaum.

Baltes, P. B., \& Baltes, M. M. (1980). Plasticity and variability in psychological aging: Methodological and theoretical issues. In G. Gurski (Ed.), Determining the effects of aging on the central nervous system (pp. 41-60). Berlin: Schering.

Baltes, P. B., Cornelius, S. W., \& Nesselroade, J. R. (1979). Cohort effects in developmental psychology. In J. R. Nesselroade \& P. B. Baltes (Eds.), Longitudinal research in the study of behavior and development (pp. 61-87). New York: Academic Press.

Baltes, P. B., Dittmann-Kohli, F., \& Dixon, R. A. (1984). New perspectives on the development of intelligence in adulthood: Toward a dualprocess conception and a model of selective optimization with compensation. In P. B. Baltes \& O. G. Brim, Jr. (Eds.), Life-span development and behavior (Vol. 6, pp. 33-76). New York: Academic Press.

Baltes, P. B., \& Kliegl, R. (1986). On the dynamics between growth and decline in the aging of intelligence and memory. In K. Poeck, H. J. Freund, \& H. Gänshirt (Eds.), Neurology (pp. 1-17). Heidelberg, West Germany: Springer Verlag.
Baltes, P. B., \& Nesselroade, J. R. (1984). Paradigm lost and paradigm regained: Critique of Dannefer's portrayal of life-span developmental psychology. American Sociological Review, 49, 841-847.

Baltes, P. B., \& Reese, H. W. (1984). The life-span perspective in developmental psychology. In M. H. Bornstein \& M. E. Lamb (Eds.), Developmental psychology: An advanced textbook (pp. 493-531). Hillsdale, NJ: Erlbaum.

Baltes, P. B., Reese, H. W., \& Lipsitt, L. P. (1980). Life-span developmental psychology. Annual Review of Psychology, 31, 65-1 10.

Baltes, P. B., Reese, H. W., \& Nesselroade, J. R. (1977). Life-span developmental psychology: Introduction to research methods. Monterey, CA: Brooks Cole.

Baltes, P. B., \& Schaie, K. W. (1976). On the plasticity of intelligence in adulthood and old age: Where Horn and Donaldson fail. American Psychologist, 31, 720-725.

Bandura, A. (1982). The psychology of chance encounters and life paths. American Psychologist, 37, 747-755.

Basseches, M. (1984). Dialectical thinking and adult development. Norwood, NJ: Ablex.

Beilin, H. (1983). The new functionalism and Piaget's program. In E. K. Scholnick (Ed.), New trends in conceptual representation. Hillsdale, NJ: Erlbaum.

Berg, C. A., \& Sternberg, R. J. (1985). A triarchic theory of intellectual development during adulthood. Developmental Review, 5, 334-370.

Bertaux, D., \& Kohli, M. (1984). The life story approach: A continental view. Annual Review of Sociology, 10, 215-237.

Birren, J. E., \& Schaie, K. W. (1985). Handbook of the psychology of aging (2nd ed.). New York: Van Nostrand Reinhold.

Brandtstädter, J. (1984). Personal and social control over development: Some implications of an action perspective in life-span developmental psychology. In P. B. Baltes \& O. G. Brim, Jr. (Eds.), Life-span development and behavior (Vol. 6, pp. 1-32). New York: Academic Press.

Brent, S. B. (1978). Individual specialization, collective adaptation, and rate of environmental change. Human Development, 21, 21-23.

Brim, O. G., Jr., \& Ryff, C. D. (1980). On the properties of life events. In P. B. Baltes \& O. G. Brim, Jr. (Eds.), Life-span development and behavior (Vol. 3, pp. 368-388). New York: Academic Press.

Brim, O. G., Jr., \& Wheeler, S. (1966). Socialization after childhood: Two essays. New York: Wiley.

Bronfenbrenner, U. (1977). Toward an experimental ecology of human development. American Psychologist, 32, 513-532.

Brown, A. L. (1982). Learning and development: The problem of compatibility, access, and induction. Human Development, 25, 89-115.

Bühler, C. (1933). Der menschliche Lebenslauf als psychologisches Problem [The human life course as a psychological topic]. Leipzig, East Germany: Hirzel.

Butler, R. N. (1963). The life-review: An interpretation of reminiscence in the aged. Psychiatry, 26,65-76.

Callahan, E. C., \& McCluskey, K. A. (Eds.). (1983). Life-span developmental psychology: Nonnormative life events. New York: Academic Press.

Carus, F. A. (1808). Psychologie. Zweiter Theil: Specialpsychologie [Psychology: Vol. 2. Special Psychology]. Leipzig, East Germany: Barth \& Kummer.

Cattell, R. B. (1971). Abilities: Their structure, growth, and action. Boston: Houghton Mifflin.

Chapman, M. (in press). Constructive evolution: Origins and development of Piaget's thought. Cambridge, England: Cambridge University Press.

Clausen, J. A. (1986). The life course: A sociological perspective. Englewood Cliffs, NJ: Prentice-Hall.

Clayton, V. P., \& Birren, J. E. (1980). The development of wisdom across the life span: A reexamination of an ancient topic. In P. B. Baites \& O. G. Brim, Jr. (Eds.), Life-span development and behavior (Vol. 3, pp. 103-135). New York: Academic Press.

Commons, M. L., Richards, F. A., \& Armon, C. (Eds.). (1984). Beyond 
formal operations: Late adolescent and adult cognitive development. New York: Praeger.

Coper, H., Jänicke, B., \& Schulze, G. (1986). Biopsychological research on adaptivity across the life span of animals. In P. B. Baltes, D. L. Featherman, \& R. M. Lerner (Eds.), Life-span development and behavior (Vol. 7, pp. 207-232). Hillsdale, NJ: Erlbaum.

Cotman, C. W. (Ed.). (1985). Synaptic plasticity. New York: Guilford Press.

Dannefer, D. (1984). Adult development and social theory: A paradigmatic reappraisal. American Sociological Review, 49, 100-116.

Dannefer, D., \& Perlmutter, M. (1986). Lifelong human development: Toward decomposition of the phenomenon and explication of its dynamics. Unpublished manuscript, University of Michigan, Ann Arbor.

Datan, N., \& Reese, H. W. (Eds.). (1977). Life-span developmental psychology: Dialectical perspectives on experimental research. New York, Academic Press.

Davies, A., Criper, C., Howatt, A. P. R. (Eds.). (1984). Interlanguage. Edinburgh, Scotland: Edinburgh University Press.

Denney, N. W. (1984). A model of cognitive development across the life span. Developmental Review; 4, 171-191.

Dittmann-Kohli, F, \& Baltes, P. B. (in press). Toward a neofunctionalist conception of adult intellectual development: Wisdom as a proto-typical case of intellectual growth. In C. Alexander \& E. Langer (Eds.), Beyond formal operations: Alternative endpoints to human development. New York: Oxford University Press.

Dixon, R. A. (1986). Contextualism and life-span developmental psychology. In R. L. Rosnow \& M. Gergoudi (Eds.), Contextualism and understanding in behavioral science (pp. 125-144). New York: Praeger.

Dixon, R. A., \& Baltes, P. B. (1986). Toward life-span research on the functions and pragmatics of intelligence. In R. J. Sternberg \& R. K. Wagner (Eds.), Practical intelligence: Origins of competence in the evervday world (pp. 203-235). New York: Cambridge University Press.

Dörner, D. (in press). Heuristics and cognition in complex systems. In R. Groner, M. Groner, \& W. F. Bischof (Eds.), Methods of heuristics. Hillsdale, NJ: Erlbaum.

Dohrenwend, B. S., \& Dohrenwend, B. P. (Eds.). (1974). Stressful life events. New York: Wiley.

Elder, G. H., Jr. (1974). Children of the Great Depression. Chicago: University of Chicago Press.

Elder, G. H., Jr. (Ed.). (1985). Life course dynamics. Ithaca, NY: Cornell University Press.

Elder, G. H., Jr., \& Liker, J. K. (1982). Hard times in women's lives: Historical influences across forty years. American Journal of Sociology, 88, 241-269.

Ericsson, K. A. (1985). Memory skill. Canadian Journal of Psychology, 39, 188-231.

Erikson, E. H. (1959). Identity and the life cycle. Psychological Issues Monograph 1. New York: International University Press.

Featherman, D. L. (1983). The life-span perspective in social science research. In P. B. Baltes \& O. G. Brim, Jr. (Eds.), Life-span development and behavior (Vol. 5, pp. 1-59). New York: Academic Press.

Featherman, D. L., \& Lerner, R. M. (1985). Ontogenesis and sociogenesis: Problematics for theory and research about development and socialization across the life span. American Sociological Review, 50, 659-676.

Ferrara, R. A., Brown, A. L., \& Campione, J. C. (1986). Children's learning and transfer of inductive reasoning rules: Studies of proximal development. Child Development, 57, 1087-1099.

Filipp, S.-H. (Ed.). (1981). Kritische Lebensereignisse [Critical life events]. Munich, West Germany: Urban \& Schwarzenberg.

Flavell, J. H. (1970). Cognitive changes in adulthood. In L. R. Goulet \& P. B. Baltes (Eds.), Life-span developmental psychology: Research and theory (pp. 247-253). New York: Academic Press.
Fries, J. F., \& Crapo, L. M. (1981). Vitality and aging. San Francisco, CA: Freeman \& Co.

Gergen, K. J. (1980). The emerging crisis in life-span developmental theory. In P. B. Baltes \& O. G. Brim, Jr. (Eds.), Life-span development and behavior (Vol. 3, pp. 32-65). New York: Academic Press.

Glaser, R. (1984). Education and thinking: The role of knowledge. American Psychologist, 39, 93-104.

Gollin, E. S. (1981). Development and plasticity. In E. S. Gollin (Ed.), Developmental plasticity: Behavioral and biological aspects of variations in development (pp. 231-251). New York: Academic Press.

Goulet, L. R., \& Baltes, P. B. (Eds.). (1970). Life-span developmental psychology: Research and theory. New York: Academic Press.

Groffmann, K. I. (1970). Life-span developmental psychology in Europe. In L. R. Goulet \& P. B. Baltes (Eds.), Life-span developmental psychology: Research and theory (pp. 54-68). New York: Academic Press.

Guthke, J. (1982). The learning test concept. An alternative to the traditional static intelligence test. The German Journal of Psychology, 6 , 306-324.

Hall, G. S. (1922). Senescence: The last half of life. New York: Appleton. Havighurst, R. J. (1972). Developmental tasks and education (3rd ed.). New York: McKay. (Original work published 1948)

Havighurst, R. J. (1973). History of developmental psychology: Socialization and personality development through the life span. In P. B. Baltes \& K. W. Schaie (Eds.), Life-span developmental psychology. Personality and socialization (pp. 3-24). New York: Academic Press.

Hetherington, E. M., \& Baltes, P. B. (in press). Child psychology and life-span development. In E. M. Hetherington, R. M. Lerner, \& M. Perlmutter (Eds.), Child development and the life-span perspective. Hillsdale, NJ: Erlbaum.

Hetherington, E. M., Lerner, R. M., \& Perlmutter, M. A. (Eds.). (in press). Child development and the life-span perspective. Hillsdale, NJ: Erlbaum.

Holliday, S. G., \& Chandler, M. J. (1986). Wisdom: Explorations in adult competence. In J. A. Meacham (Ed.), Contributions to human development (Vol. 17). Basel, Switzerland: Karger.

Hollingworth, H. L. (1927). Mental growth and decline: $A$ survey of developmental psychology. New York: Appleton.

Honzik, M. P. (1984). Life-span development. Annual Review of Psychology, 33, 309-331.

Horn, J. L. (1970). Organization of data on life-span development of human abilities. In L. R. Goulet \& P. B. Baltes (Eds.), Life-span developmental psychology: Research and theory (pp. 423-466). New York: Academic Press.

Horn, J. L. (1982). The theory of fluid and crystallized intelligence in relation to concepts of cognitive psychology and aging in adulthood. In F. I. M. Craik \& S. E. Trehub (Eds.), Aging and cognitive processes (pp. 847-870). New York: Plenum Press.

Horn, J. L., \& Donaldson, G. (1976). On the myth of intellectual decline in adulthood. American Psychologist. 31, 701-719.

Hoyer, W. J. (1985). Aging and the development of expert cognition. In T. M. Schlechter \& M. P. Toglia (Eds.), New directions in cognitive science (pp. 69-87). Norwood, NJ: Ablex.

Hultsch, D. F., \& Plemons, J. K. (1979). Life events and life-span development. In P. B. Baltes \& O. G. Brim, Jr. (Eds.), Life-span development and behavior (Vol. 2, pp. 1-37). New York: Academic Press.

Joerißen, P., \& Will, C. (1983). Die Lebenstreppe: Bilder der menschlichen Lebensalter [The steps of life: Art and the human ages]. Cologne, West Germany: Rheinland-Verlag.

Jung, C. G. (1933). Modern man in search of a soul. New York: Harcourt, Brace, \& World.

Kaplan, B. (1983). A trio of trials. In R. M. Lerner(Ed.), Developmental psychology: Historical and philosophical perspectives (pp. 185-228). Hillsdale, NJ: Erlbaum.

Keating, D., \& MacLean, D. (in press). Reconstruction in cognitive development: A post-structuralist agenda. In P. B. Baltes, D. L. Feather- 
man, \& R. M. Lerner (Eds.), Life-span development and behavior (Vol. 8). Hillsdale, NJ: Erlbaum.

Keil, F. C. (1981). Constraints on knowledge and cognitive development. Psychological Review, 88, 187-227.

Kellerman, E., \& Smith, M. S. (1986). Crosslinguistic influence in second language acquisition. Oxford, England: Pergamon Press.

Kendler, T. S. (1979). Cross-sectional research, longitudinal theory, and a discriminative transfer ontogeny. Human Development, 22, 235254.

Kendler, T. S. (1986). World views and the concept of development: A reply to Lerner and Kauffman. Developmental Review, 6, 80-95.

Kertzer, D. I., \& Keith, J. (Eds.). (1983). Age and anthropological theory. Ithaca. NY: Cornell University Press.

Kirkwood, T. B. L. (1985). Comparative and evolutionary aspects of longevity. In C. E. Finch \& E. L. Schneider (Eds.), Handbook of the biology of aging (pp. 27-44). New York: Van Nostrand Reinhold.

Kliegl, R., \& Baltes, P. B. (1987). Theory-guided analysis of development and aging mechanisms through testing-the-limits and research on expertise. In C. Schooler \& K. W. Schaie (Eds.), Cognitive functioning and social structure over the life course (pp. 95-119). Norwood, NJ: Ablex.

Kliegl, R., Smith, J., \& Baltes, P. B. ( 1986). Testing-the-limits, expertise, and memory in adulthood and old age. In F. Klix \& H. Hagendorf (Eds.), Human memory and cognitive capabilities: Mechanisms and performances (pp. 395-407). Amsterdam, Netherlands: North Holland.

Kramer, D. A. (1983). Postformal operations? A need for further conceptualization. Human Development, 26, 91-105.

Labouvie, E. W., \& Nesselroade, J. R. (1985). Age, period, and cohort analysis and the study of individual development and social change. In J. R. Nesselroade \& A. von Eye (Eds.), Developmental and social change: Explanatory analysis (pp. 189-212). New York: Academic Press.

Labouvie-Vief, G. (1980). Beyond formal operations: Uses and limits of pure logic in life-span development. Human Development, 23, 141-161.

Labouvie-Vief, G. (1982). Dynamic development and mature autonomy: A theoretical prologue. Human Development, 25, 161-191.

Labouvie-Vief, G. (1985). Intelligence and cognition. In J. E. Birren \& K. W. Schaie (Eds.), Handbook of the psychology of aging (2nd ed., pp. 500-530). New York: Van Nostrand Reinhold.

Labouvic-Vief, G., \& Chandler, M. (1978). Cognitive development and life-span developmental theory: Idealistic versus contextual perspectives. In P. B. Baltes (Ed.), Life-span development and behavior (Vol. 1, pp. 181-210). New York: Academic Press.

Lerner, R. M. (1984). On the nature of human plasticity. New York: Cambridge University Press.

Lerner, R. M., \& Kauffman, M. B. (1985). The concept of development in contextualism. Developmental Review, 5, 309-333.

Lerner, R. M., \& Kauffman, M. B. (1986). On the metatheoretical relativism of analyses of metatheoretical analyses: A critique of Kendler's comments. Developmental Review, 6, 96-106.

McCall, R. B. (1979). The development of intellectual functioning in infancy and the prediction of later IQ. In J. Osofsky (Ed.), Handbook of infant development (pp. 707-741). New York: Wiley.

McCluskey, K. A., \& Reese, H. W. (Eds.). (1984). Life-span developmental psychology: Historical and generational effects. New York: Academic Press.

McGraw, M. (1985). Professional and personal blunder in child development research. In J. Osofsky (Ed.), Newsletter of the Society for Research in Child Development, Special Supplement to Winter Newsletter.

Meacham, J. A. (1982). Wisdom and the context of knowledge: Knowing that one doesn't know. In D. Kuhn \& J. A. Meacham (Eds.), On the development of developmental psychology (pp. 111-134). Basel, Switzerland: Karger.
Migdal, S., Abeles, R., \& Sherrod, L. (1981). An inventory of longitudinal studies of middle and old age. New York: Social Science Research Council.

Montada, L. (1979). Entwicklungspsychologie auf der Suche nach einer Identität [Developmental psychology in search of an identity]. In L. Montada (Ed.), Brennpunkte der Entwicklungspsychologie [Current foci in developmental psychology] (pp. 31-44). Stuttgart, West Germany: Kohlhammer.

Neisser, U. (Ed.). (1982). Memory observed: Remembering in natural contexts. San Francisco, CA: Freeman.

Nesselroade, J. R., \& Baltes, P. B. (1974). Adolescent personality development and historical change: 1970-72. Monographs of the Society for Research in Child Development, $39(1$, Serial No. 154).

Nesselroade, J. R., \& von Eye, A. (Eds.). (1985). Developmental and social change: Explanatory analysis. New York: Academic Press.

Neugarten, B. L., \& Datan, N. (1973). Sociological perspectives on the life cycle. In P. B. Baltes \& K. W. Schaie (Eds.), Life-span developmental psychology: Personality and socialization (pp. 53-69). New York: Academic Press.

Nisbet, R. (1980). History of the idea of progress. New York: Basic Books.

Oerter, R. (1986). Developmental task through the life span: A new approach to an old concept. In P. B. Baltes, D. L. Featherman, \& R. M. Lerner (Eds.), Life-span development and behavior (Vol. 7, pp. 233269). Hillsdale, NJ: Erlbaum.

Parke, R. D., \& Tinsley, B. R. (1984). Fatherhood: Historical and contemporary perspectives. In K. A. McClusky \& H. W. Reese (Eds.), Life-span developmental psychology: Historical and generational effects. New York: Academic Press.

Pascual-Leone, J. (1983). Growing into human maturity: Toward a metasubjective theory of adulthood stages. In P. B. Baltes \& O. G. Brim, Jr. (Eds.), Life-span development and behavior (Vol. 5, pp. 118 156). New York: Academic Press.

Perlmutter, M. (in press). Cognitive development in life-span perspective: From description of differences to explanation of changes. In E. M. Hetherington, R. M. Lerner, \& M. Perlmutter (Eds.), Child development in life-span perspective. Hillsdale, NJ: Erlbaum.

Philibert, M. (1968). L'échelle des ages [The ladder of ages]. Paris: Seuil. Piaget, J. (1969). The mechanisms of perception. London: Routledge \& Kegan Paul.

Piaget, J. (1972). Intellectual evolution from adolescence to adulthood. Human Development, 15, 1-12.

Porges, S. W. (1976). Cohort effects and apparent secular trends in infant research. In K. F. Riegel \& J. A. Meacham (Eds.), The developing individual in a changing world (Vol. 2, pp. 687-695). Chicago: Aldine.

Quetelet, A. (1835). Sur l'homme et le développement de ses facultés [On man and the development of his faculties]. Paris: Bachelier.

Reese, H. W. (1974). Cohort, age, and imagery in children's pairedassociate learning. Child Development, 45, 1176-1178.

Reese, H. W., \& Overton, W. F. (1970). Models of development and theories of development. In L. R. Goulet \& P. B. Baltes (Eds.), Lifespan developmental psychology: Research and theory (pp. 115-145). New York: Academic Press.

Reinert, G. (1979). Prolegomena to a history of life-span developmental psychology. In P. B. Baltes \& O. G. Brim, Jr. (Eds.), Life-span development and behavior (Vol. 2, pp. 205-254). New York: Academic Press.

Riegel, K. F. (1973). Dialectical operations: The final period of cognitive development. Human Development, 16, 346-370.

Riegel, K. F. (1976). The dialectics of human development. American Psychologist, 31, 689-700.

Riley, M. W. (1985). Age strata in social systems. In R. H. Binstock \& E. Shanas (Eds.), Handbook of aging and the social sciences (Vol. 3, pp. 369-411). New York: Van Nostrand Reinhold.

Riley, M. W., Johnson, M., \& Foner, A. (Eds.). (1972). Aging and society: Vol. 3. A sociology of age stratification. New York: Russell Sage. 
Ross, L. (1981). The "intuitive scientist" formulation and its development implications. In L. Ross \& J. Flavell (Eds.), Social cognitive development (pp. 1 42). New York: Cambridge University Press.

Rybash, J. M., Hoyer, W., \& Roodin, P. A. (1986). Adult cognition and aging: Developmental changes in processing, knowing, and thinking. New York: Pergamon Press.

Salthouse, T. A. (1984). Effects of age and skill in typing. Journal of Experimental Psychology: General, 113, 345-371.

Salthouse, T. A. (1985). A theory of cognitive aging. Amsterdam, Netherlands: North Holland.

Scarr, S. (1986). How plastic are we? Contemporary Psychology, 3I, 565-567.

Schaie, K. W. (1965). A general model for the study of developmental problems. Psychological Bulletin, 64, 92-107.

Schaie, K. W. (1979). The primary mental abilities in adulthood: An exploration in the development of psychometric intelligence. In P. B. Baltes \& O. G. Brim, Jr. (Eds.), Life-span development and behavior (Vol. 3, pp. 67-115). New York: Academic Press.

Schaie, K. W. (Ed.). (1983). Longitudinal studies of adult psychological development. New York: Guilford Press.

Schaie, K. W., \& Willis, S. L. (1986). Can adult intellectual decline be reversed? Developmental Psychology, 22, 223-232.

Scholnick, E. K. (1985). Unlimited development. Contemporary Psychology, 30, 314-316.

Sears, R. R. (1980). A new school of life span? Contemporary Psychology $25,303-304$.

Sears, E. (1986). Ages of man: Medieval interpretations of the life cycle. Princeton, NJ: Princeton University Press.

Sherrod, L. R., \& Brim, O. G., Jr. (1986). Retrospective and prospective views of life-course research on human development. In A. B. Sorensen, F. E. Weinert, \& L. R. Sherrod (Eds.), Human development and the life course: Multidisciplinary perspectives. Hillsdale, NJ: Erlbaum.

Skinner, B. F. (1983). Intellectual self-management in old age. American Psychologist, 38, 239-244.

Smith, J., Dixon, R. A., \& Baltes, P. B. (in press). Expertise in life planning: A new approach to investigating aspects of wisdom. In M. L. Commons, J. D. Sinnott, F. A. Richards, \& C. Armon (Eds.), Beyond formal operations II. New York: Praeger.

Smith, J., Kliegl, R., \& Baltes, P. B. (1987). Testing-the-limits and the study of age differences in cognitive plasticity: The sample case of expert memory. Manuscript submitted for publication.

Sternberg, R. J. (in press). Lessons from the life span: What theorists of intellectual development among children can learn from their coun- terparts studying adults. In E. M. Hetherington, R. M. Lerner, \& M. Perlmutter (Eds.), Child development in life-span perspective. Hillsdale, NJ: Erlbaum.

Sternberg, R. J., \& Wagner, R. K. (Eds.). (1986). Practical intelligence: Nature and origins of competence in the everyday world. New York: Cambridge University Press.

Strube, G. (1985). Knowing what's going to happen in life: 2. Biographical knowledge in developmental perspective. Unpublished manuscript, Max Planck Institute for Psychological Research, Munich, West Germany.

Tetens, J. N. (1777). Philosophische Versuche über die menschliche Natur und ihre Entwicklung [Philosophical essays on human nature and its development]. Leipzig, East Germany: Weidmanns Erben und Reich.

Thomae, H. (1979). The concept of development and life-span developmental psychology. In P. B. Baites \& O. G. Brim, Jr. (Eds.), Life-span development and behovior (Vol. 2, pp. 282-3/2). New York: Academic Press.

Tinsley, B. R., \& Parke, R. D. (1984). Grandparents as support and socialization agents. In M. Lewis (Ed.), Beyond the dyad. New York: Plenum.

Verdonik, F., \& Sherrod, L. (1984). An inventory of longitudinal research on childhood and adolescence. New York: Social Science Research Council.

Waddington, C. H. (1975). The evolution of an evolutionist. Edinburgh, Scotland: Edinburgh University Press.

Weinert, F. E., Schneider, W., \& Knopf, M. (in press). Individual differences in memory development across the life span. In P. B. Baltes, D. L. Featherman, \& R. M. Lerner (Eds.), Life-span development and behavior (Vol. 9). Hillsdale, NJ: Erlbaum.

Weir, M. W. (1964). Developmental changes in problem-solving strategies. Psychological Review, 71, 473-490.

Wiedl, K. H. (1984). Lerntests: Nur Forschungsmittel und Forschungsgegenstand? [Tests of learning: Only a strategy and topic of research?] Zeitschrift für Entwicklungspsychologie und Pädagogische Psychologie, 16, 245-281.

Willis, S. L. (1985). Towards an educational psychology of the adult learner. In J. E. Birren \& K. W. Schaie (Eds.), Handbook of the psychology of aging (pp. 818-847). New York: Van Nostrand Reinhold.

Wohlwill, J. F. (1973). The study of behavioral development. New York: Academic Press.

Received July 22, 1986

Revision received March 16, 1987

Accepted March 23, 1987 